\title{
A combined LC-MS/MS and molecular networking approach reveals new cyanotoxins from the 2014 cyanobacterial bloom in Green Lake, Seattle
}

\author{
Roberta Teta $^{\dagger}$, Gerardo Della Sala ${ }^{\dagger}$, Evgenia Glukhov ${ }^{\ddagger}$, Lena Gerwick ${ }^{\ddagger}$, William H. Gerwick ${ }^{\ddagger}$, \\ Alfonso Mangoni ${ }^{\dagger}$, and Valeria Costantinot, ${ }^{*}$ \\ †The NeaNat Group (www.neanat.unina.it), Dipartimento di Farmacia, Universita degli Studi di \\ Napoli Federico II, via D. Montesano 49, 80131 Napoli, Italy \\ ₹Center for Marine Biotechnology and Biomedicine, Scripps Institution of Oceanography, and \\ Skaggs School of Pharmacy and Pharmaceutical Sciences, University of California at San Diego, \\ 9500 Gilman Drive, MC 0212, La Jolla, CA 92093-0212, USA
}

\begin{abstract}
Cyanotoxins obtained from a freshwater cyanobacterial collection at Green Lake, Seattle during a cyanobacterial harmful algal bloom in the summer of 2014 were studied using a new approach based on molecular networking analysis of liquid chromatography-tandem mass spectrometry (LC-MS/MS) data. This MS-networking approach is particularly well suited for the detection of new cyanotoxin variants, and resulted in the discovery of three new cyclic peptides, namely microcystin-MhtyR (6) which comprised about half of the total microcystin content in the bloom, and ferintoic acids C (12) and D (13). Structure elucidation of 6 was aided by a new microscale methylation procedure. Metagenomic analysis of the bloom using the 16S-ITS rRNA region identified Microcystis aeruginosa as the predominant cyanobacterium in the sample. Fragments of the putative biosynthetic genes for the new cyanotoxins were also identified, and their sequences correlated to the structure of the isolated cyanotoxins.
\end{abstract}

\section{Graphical abstract}

\footnotetext{
*Corresponding Author: Phone: +39-081-678-504. valeria.costantino@unina.it.

Notes

The authors declare no competing financial interest.

ASSOCIATED CONTENT

Supporting Information. Tables S1 and S2 containing BLAST matches of the amplified 16S-ITS rRNA, mcyBAd1, and ferBAd1 fragments. Figure S1 showing the structures of thiol derivatives of MCs, and Figure S2 showing their LC-MS analysis. Figures S3S13 showing HR-MS/MS spectra of 1-8 and 11-13.
} 


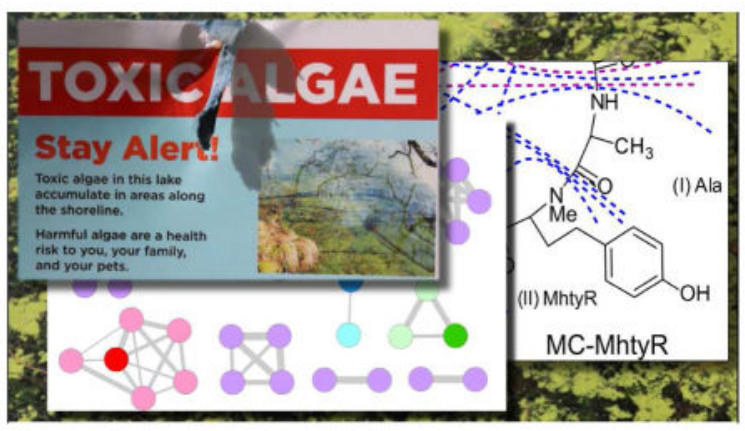

\section{INTRODUCTION}

Cyanobacteria have a long history of ecological and health impacts. This unique class of photosynthetic microorganisms can generally survive in nearly all phototrophic aquatic environments, including recreational water bodies, fisheries, and reservoirs. In the last two decades, worldwide attention has been given to the ecological effects of cyanobacteria and to their production of secondary metabolites. They represent a not yet fully explored source of novel lead compounds for drug discovery, such as the dolastatins, ${ }^{1}$ cryptophycins, ${ }^{2}$ and curacins, ${ }^{3}$ that have in turn inspired the development of synthetic analogues with improved bioactivity and pharmacokinetics. Some of these have successfully reached the phase II and phase III of clinical trials, and one is a FDA clinically approved drug. ${ }^{4}$ In addition, it has been shown that symbiotic cyanobacteria are often the real producers of secondary metabolites that were originally isolated and thought to be produced by invertebrates. $5,6,7$ Interestingly, smenothiazole B ${ }^{8}$ recently isolated from the sponge Smenospongia aurea during our anticancer screening program, closely resembles that of the neurotoxin jamaicamide B, ${ }^{9}$ a hybrid peptide/polyketide obtained from the cyanobacterium Moorea producens (formerly known as Lyngbya majuscula). The two molecules share a similar vinyl chloride moiety and alkynyl terminus.

On the other hand, cyanobacteria growing in freshwater and marine recreational areas may have a strongly negative impact on human health. Some species can form extensive blooms, and there is evidence that these are increasing during recent decades due to nutrient enrichment, especially phosphorus. ${ }^{10}$ Many cyanobacteria produce toxic secondary metabolites (cyanotoxins) with differing effects on health, ranging from mild skin irritations to severe illness. ${ }^{11}$ Economic losses from freshwater and marine cyanobacterial blooms in the United States account for millions of dollars per year, and include monitoring programs, closure of recreational areas and fisheries, loss of livestock, water treatment and population wellness related costs. ${ }^{12}$

Because cyanobacteria are an attractive research topic from both the risks as well as potential remedies they represent, we have initiated a worldwide program to study their chemistry and biochemistry. Here we report our analysis of a sample of the cyanobacterial scum collected at Green Lake, Seattle (WA, USA) during the 2014 summer bloom. This study involved a new approach that combined liquid chromatography (LC)-high resolution mass spectrometry (HRMS) with automated data analysis using the molecular networking 
technique, ${ }^{13}$ and led to the rapid identification of one new microcystin (MC) (6) and two new ferintoic acid congeners (12 and 13). In addition, metagenomic analysis of the sample allowed us to identify the bloom-forming cyanobacteria as a strain of Microcystis aeruginosa, and to detect a fragment of the mcyBAd1 gene from the MC biosynthetic cluster. The sequence and predicted function of this gene nicely correlate with the structure of the MCs detected in the sample.

\section{MATERIAL AND METHODS}

\section{Collection and Extraction}

A sample of cyanobacterial scum was collected at Green Lake, Seattle (WA, USA) on September 5, 2014 during a cyanobacterial harmful algal bloom. A voucher sample is stored at Dipartimento di Farmacia, Universita degli Studi di Napoli "Federico II" with the reference number SEAGL14. An aliquot $(2 \mathrm{~mL})$ of the cyanobacterial suspension was sonicated for $5 \mathrm{~min}$ and extracted with $\mathrm{BuOH}$. The organic and aqueous layers were separated, filtered (Whatman, $0.2 \mu \mathrm{m}$, PTFE) and dried, yielding $1 \mathrm{mg}$ of dry organic extract; the extract was resuspended in $\mathrm{H}_{2} \mathrm{O}$ at a concentration of $5 \mathrm{mg} / \mathrm{mL}$ and subsequently analyzed by LC-HRMS.

The $\mathrm{BuOH}$ extract was subjected to preparative reversed-phase HPLC separation on a Agilent 1260 Infinity Quaternary LC apparatus equipped with a Diode-Array Detector (DAD) [column $150 \times 4.6 \mathrm{~mm}, 5 \mu \mathrm{m}$, Kinetex $\mathrm{C} 18$; eluent $\mathrm{A}$ : $\mathrm{H}_{2} \mathrm{O}$; eluent $\mathrm{B}$ : $\mathrm{ACN}$; gradient: $20 \rightarrow 99 \% \mathrm{~B}$, over $22 \mathrm{~min}$, flow rate $0.2 \mathrm{~mL} / \mathrm{min}$ ], which afforded two fractions (fraction $\mathrm{A}, t_{\mathrm{R}}=15 \mathrm{~min}$, and fraction $\mathrm{B}, t_{\mathrm{R}}=16 \mathrm{~min}$ ) containing, respectively, MC-HtyrR (5) and MC-MhtyR (6) (Figure 2) as the sole microcystins, as determined by LC-HRMS analysis.

\section{LC-HRMS and LC-HRMS/MS}

Experiments were performed using a Thermo LTQ Orbitrap XL high-resolution ESI mass spectrometer coupled to an Agilent model 1100 LC system, which included a solvent reservoir, in-line degasser, binary pump, and refrigerated autosampler. A $5 \mu \mathrm{m}$ Kinetex C18 column $(50 \times 2.1 \mathrm{~mm})$, maintained at $25{ }^{\circ} \mathrm{C}$, was operated using a gradient elution of $\mathrm{H}_{2} \mathrm{O}$ and ACN running at $200 \mu \mathrm{L} / \mathrm{mim}$. The gradient program was as follows: $10 \% \mathrm{ACN}$ for 5 min, $10 \%-99 \%$ ACN over $17 \mathrm{~min}, 99 \%$ ACN for 3 min. All the mass spectra were recorded in the positive-ion mode. MS parameters were a spray voltage of $5 \mathrm{kV}$, a capillary temperature of $230{ }^{\circ} \mathrm{C}$, a sheath gas rate of 15 units $\mathrm{N}_{2}$ (ca. $150 \mathrm{~mL} / \mathrm{min}$ ), and an auxiliary gas rate of 5 units $\mathrm{N}_{2}$ (ca. $50 \mathrm{~mL} / \mathrm{min}$ ). Data were collected in the data-dependent acquisition (DDA) mode, in which the first and second most intense ions of a full-scan mass spectrum were subjected to tandem mass spectrometry (MS/MS) analysis. MS/MS scans were obtained for selected ions with CID fragmentation, isolation width 2.0, normalized collision energy 36, Activation Q 0.250 , and activation time $30 \mathrm{~ms}$. Mass data were analyzed using the Thermo Xcalibur software. 


\section{Methylation of microcystins}

A mixture containing MC-LR and MC-YR (Sigma) (1.75 $\mu$ g each) in $350 \mu \mathrm{L}$ of $\mathrm{MeOH}$ was treated with (trimethylsilyl)diazomethane (2M solution in $\left.\mathrm{Et}_{2} \mathrm{O}, 100 \mu \mathrm{L}\right) .{ }^{14}$ The reaction mixture was kept at room temperature overnight, then dried and redissolved in $\mathrm{H}_{2} \mathrm{O} / \mathrm{MeOH}$ (9:1) $(100 \mu \mathrm{L})$ for subsequent LC-HRMS analysis. Similarly, fraction A $(0.2 \mathrm{mg})$ and fraction B $(0.5 \mathrm{mg})$ from the HPLC separation described above were each dissolved in 400 $\mu \mathrm{L}$ of $\mathrm{MeOH}$ and methylated with (trimethylsilyl)diazomethane $(50 \mu \mathrm{L}, 2 \mathrm{M}$ solution in $\left.\mathrm{Et}_{2} \mathrm{O}\right)$ as described above.

\section{Molecular Networking}

The mass spectral data were converted to mzXML format using the program msconvert. ${ }^{15} \mathrm{~A}$ molecular network was obtained using the online workflow at the GNPS website. ${ }^{16}$ The data was then clustered with MS-Cluster with a parent mass tolerance of 2.0 Da and a MS/MS fragment ion tolerance of $0.1 \mathrm{Da}$ to create consensus spectra. Further, consensus spectra that contained less than 2 spectra were discarded. A network was then created where edges were filtered to have a cosine score above 0.6 and more than 10 matched peaks. Furthermore, edges between two nodes were kept in the network only if each of the nodes appeared in each other's respective top 10 most similar nodes. The spectra in the network were then searched against GNPS's spectral libraries. The data were then imported into Cytoscape 2.8.3 $3^{17}$ and displayed as a network of nodes and edges. The network was organized with the FM3 layout plug-in. ${ }^{18}$ Dereplication and search for analogues were performed separately after the creation of the network. All matches within the library spectra were required to have a score above 0.7 and at least 10 matched peaks with a parent mass tolerance of $2.0 \mathrm{Da}$ and a MS/MS fragment ion tolerance of $0.5 \mathrm{Da}$. Analogue search was enabled against the library with a maximum mass shift of $200 \mathrm{Da}$.

\section{DNA isolation, PCR amplification, and clone library construction}

Metagenomic DNA from the Green Lake cyanobacteria was extracted from a pellet (about $40 \mathrm{mg}$ ) obtained by centrifugation of the cyanobacterial scum. Primers used in the PCR experiments were the 16S-ITS rRNA cyanobacterial specific primers CYA359F (5'GGGGAATYTTCCGCAATGGG-3' ${ }^{\prime}{ }^{19}$ and 373R (5'-CTAACCACCTGAGCTAAT-3'), ${ }^{20}$ the specific $m c y B$ primers FAA (5'-CTATGTTATTTATACATCAGG - $\left.3^{\prime}\right)$ and RAA (5'CTCAGCTTAACTTGATTATC $\left.-3^{\prime}\right),{ }^{21}$ and the degenerate primers MTF $\left(5^{\prime}\right.$ GCNGGYGGYGCNTAYGTNCC-3') and MTR (5'-CCNCGDATYTTNACYTG-3'). ${ }^{21}$ PCR products were subcloned with the TOPO TA cloning $\mathrm{R}_{\mathrm{R}}$ kit (Invitrogen) and sequenced. Sequences were analyzed by the RDP Seq Match tool, ${ }^{22}$ BLASTn $^{23}$ and BLASTx. Full experimental details are reported in the Supporting Information.

Partial sequences of 16S-ITS rDNA from Microcystis aeruginosa SEAGL14, mcyB_Ad1, and ferB_Ad were deposited into GenBank under the accession numbers KT359577KT359579. 


\section{RESULTS}

\section{Molecular Networking}

A cyanobacterial bloom sample collected from Green Lake (Seattle, WA, USA) during the bloom occurring in the summer 2014 was extracted and analyzed by LC HRMS and LCHRMS/MS. Data obtained were used to generate a molecular network using the Global Natural Product Social Molecular Network (GNPS) ${ }^{16}$ (See Experimental section for details). The mass spectral molecular networking results in a fast identification of known metabolites from natural extracts (dereplication) ${ }^{13}$ as well as new analogues. ${ }^{24}$ Molecular networking provides a visual representation of structural relationships as revealed by MS/MS data. A single chemical species is represented as a node and the relatedness between compounds is represented by an edge.

Libraries containing a large number of MS/MS spectra of known natural products are available at the GNPS website for the purpose of dereplication (additionally, users can provide their own libraries). During the process of generation of the network, the spectra from one or more LC MS/MS runs are compared pairwise, and each spectrum is also compared with spectra in the libraries. This strategy allows the identification not only of known metabolites, but also of their structural analogues (either new or known compounds which are not present in the library) in a fast and automatic way, and directly from raw LCMS/MS data. To date, this new approach has not yet been used in the analysis of a cyanobacterial bloom.

Because the data obtained in this study were high-resolution MS/MS spectra, we reasoned that smaller values for the MS/MS fragment ion tolerance than the default $0.5 \mathrm{Da}$ would improve the quality of the network and minimize false clusters between structurally unrelated compounds. After some trials, we empirically determined an optimal value of 0.1 Da for this parameter. Moreover, because peptides are known to contain a large number of fragment ions, we selected a threshold of 10 matched peaks (compared to the default of 6 peaks) for two nodes to be connected. The Green Lake two-dimensional network obtained using these parameters, and visualized using the Cytoscape software, ${ }^{17}$ is displayed in Figure 1. The network contains 13 clusters ranging from 2 to 10 nodes.

Dereplication and search for analogues were performed separately after the creation of the network, in part because not all of the available libraries of natural products contained highresolution spectra. Therefore, the default MS/MS fragment ion tolerance of 0.5 Da was restored, and the specific dereplication workflow available at the GNPS website was used. This resulted in the identification of three known cyanobacterial compounds, namely microcystins LR (1), ${ }^{25}$ ferintoic acid A (11),${ }^{26}$ and aerucyclamide A, ${ }^{27}$ along with several analogues of these metabolites. The corresponding nodes of Figure 1 are color-coded accordingly.

While the molecular networking algorithm allows a fast and automated identification of analogs of known compounds, it does not directly provide a chemical structure for these analogues. Therefore, the structures of the analogues of microcystin and ferintoic acids were 
established from an in-depth analysis of the high resolution MS/MS spectra combined with nanogram-scale chemical derivatization.

\section{Microcystins}

MCs are monocyclic heptapeptides biosynthesized via the nonribosomal peptide synthetase (NRPS) pathway as encoded by the mcy gene cluster. ${ }^{28}$ MCs contain a common set of five amino acids (including the unique $\beta$-amino acid 3-amino-9-methoxy-2,6,8-trimethyl-10phenyl-4,6-decadienoic acid, or Adda) and two variable L-amino acids at positions 2 and 4. MCs are named after their variable L-amino acids. The most common MC, which contains leucine (L) at position 2 and arginine (R) at position 4, is therefore called MC-LR (1, Figure 2). Substitutions at position 2 and 4 give rise to more than 20 primary MC analogues, with alterations in other constituent amino acids resulting in more than 100 reported MCs to date. ${ }^{29,30} \mathrm{MCs}$ are hepatotoxins; they are strong inhibitors of type 1 and $2 \mathrm{~A}$ serine protein phosphatases (PP1 and PP2A). ${ }^{31}$ These enzymes are vital to various cellular processes such as cell growth and tumor suppression and therefore these toxins are potent potential cancer promoters. $^{32}$

The MC cluster contained six nodes, indicating the presence of five compounds closely related to MC-LR $(1, \mathrm{~m} / \mathrm{z}$ 995.5535). The relative amounts of the six MCs were estimated from the areas of the relevant peaks in the extracted-ion chromatograms from the LC-MS run (Figure 2). The molecular weight of $\mathbf{2}(\mathrm{m} / \mathrm{z} 1029.5361)$ and $\mathbf{3}(\mathrm{m} / \mathrm{z}$ 1045.5320) suggested they were the relatively common MC variants, MC-FR and MC-YR, respectively. This was confirmed by comparison of their retention times and MS/MS spectra with those of authentic standards. The high-resolution MS/MS fragmentation patterns of 1-3 were studied in detail (Figure 3). Most fragment ions derived from the cleavage of two amide bonds, which is the typical fragmentation mode of cyclic peptides. ${ }^{33}$ In all of these fragment ions, the positive charge was retained on the fragment containing arginine. Fragments deriving from the loss of part of the Adda residue (ions $a, 1$, and $m$ in Figure 3) were also observed. These analyses completed and confirmed previous interpretations of low- resolution ${ }^{34}$ and high-resolution ${ }^{35}$ spectra of MCs, and provided a basis for the subsequent analysis of the MS/MS spectra of MCs 4-6.

The molecular formula of $\mathbf{4}(\mathrm{m} / \mathrm{z}$ 1049.5633) indicated the presence of four additional hydrogen atoms compared to MC-YR (3). Analysis of the MS/MS spectrum showed that all of the ions containing amino acid 2 were shifted to higher mass by $4 \mathrm{Da}$, while the remaining ions were unchanged, thus locating the additional four $\mathrm{H}$-atoms on amino acid 2 (Tyr in MC-YR). These data are consistent with MC- $\left(\mathrm{H}_{4}\right) \mathrm{YR}$, a known MC containing a 1,2,3,4-tetrahydrotyrosine residue. ${ }^{36,37}$

Compound 5 ( $\mathrm{m} / \mathrm{z}$ 1059.5480) showed an additional $\mathrm{CH}_{2}$ compared with MC-YR (3); this was also located at the amino acid 2 position (Figure 3), suggesting the presence of a homotyrosine residue. Homotyrosine is frequently found in MCs, but its presence (rather than the isomeric $O$-methyl tyrosine that is also found in cyanobacterial peptides) ${ }^{38}$ is not always confirmed experimentally. In our case, the presence of a homotyrosine residue was confirmed by chemical derivatization as described in the following section. 
The new MC $6\left(\mathrm{~m} / \mathrm{z}\right.$ 1073.5630) showed an additional $\mathrm{CH}_{2}$ compared to MC-HtyR (5), and once again, MS/MS fragment ions demonstrated that the additional 14 Da mass belonged to amino acid 2 (Figure 3). However, because all fragment ions (except those involving cleavage of Adda) contained intact amino acids, it was not possible to establish the exact location of this $\mathrm{CH}_{2}$ group on the homotyrosine residue from MS/MS data alone. Two structures seemed most reasonable, either an $O$-methylated homotyrosine or an $N$ methylated homotyrosine residue at position 2. It was not possible to obtain $\mathbf{6}$ in sufficient quantity for NMR analysis. Therefore, a microscale $O$-methylation procedure was developed and used to distinguish between the two possible structures.

\section{Methylation of microcystins}

(Trimethylsilyl)diazomethane $\left(\mathrm{TMSCHN}_{2}\right)$, a less hazardous analogue of diazomethane with essentially the same reactivity, methylates phenols to quantitatively yield the corresponding methyl ethers, ${ }^{14}$ and was therefore chosen as the reagent for $O$-methylation of the MCs. Additionally, it was expected that $\mathrm{TMSCHN}_{2}$ would also react with the two carboxylic groups present in the MCs, and therefore the reagent was preliminary tested with a standard sample of MC-LR (1). Surprisingly, even with a very large excess of $\mathrm{TMSCHN}_{2}$ and long reaction times, only the monomethyl derivative $7\left(\mathrm{~m} / \mathrm{z} 1009.5712, \mathrm{C}_{50} \mathrm{H}_{77} \mathrm{~N}_{10} \mathrm{O}_{12}\right.$, additional $\mathrm{CH}_{2}$ compared to 1) of MC-LR was obtained. LC-HRMS/MS analysis of the reaction product showed that methylation occurred on the Glu residue, while the MeAsp residue did not react (Figure 4). This can be explained by the formation of a strong ion pair interaction between the MeAsp carboxylate and the Arg guanidinium groups. The reaction was then repeated using MC-YR (3), and the bis-methylated product $8(\mathrm{~m} / z$ 1073.5678, $\mathrm{C}_{54} \mathrm{H}_{77} \mathrm{~N}_{10} \mathrm{O}_{13}$, additional $\mathrm{C}_{2} \mathrm{H}_{4}$ compared to 3 ) was formed. Compound $\mathbf{8}$ was shown to be methylated on the Glu and Tyr residues (Figure 4), and confirmed that $\mathrm{TMSCHN}_{2}$ was capable of reacting with the Tyr phenolic hydroxy group.

Finally, the reaction was performed on two HPLC fractions of the $\mathrm{BuOH}$ extract (fractions A and B), which respectively contained MC-HtyR (5) and MC-MhtyR (6) as the only MCs. The reactions yielded, respectively, the bis-methylated products $\mathbf{9}(\mathrm{m} / \mathrm{z} 1087.5834$, $\mathrm{C}_{55} \mathrm{H}_{79} \mathrm{~N}_{10} \mathrm{O}_{13}$, additional $\mathrm{C}_{2} \mathrm{H}_{4}$ compared to 5) and $\mathbf{1 0}\left(\mathrm{m} / z 1101.5979, \mathrm{C}_{56} \mathrm{H}_{81} \mathrm{~N}_{10} \mathrm{O}_{13}\right.$, additional $\mathrm{C}_{2} \mathrm{H}_{4}$ compared to 6). Unfortunately, the MS/MS spectra of 9 and $\mathbf{1 0}$ displayed low intensity, and most fragment peaks were obscured by noise. However, the diagnostic ions formed by loss of MeAsp (ion $g, \mathrm{~m} / \mathrm{z} 958.5376$ and $\mathrm{C}_{50} \mathrm{H}_{72} \mathrm{~N}_{9} \mathrm{O}_{10}{ }^{+}$for $\mathbf{9}$ and 972.5539 and $\mathrm{C}_{51} \mathrm{H}_{74} \mathrm{~N}_{9} \mathrm{O}_{10}{ }^{+}$for $\mathbf{1 0}$ ) were still detectable, and confirmed that no methylation had occurred at this amino acid residue. These results showed that both MC-HtyR (5) and MCMhtyR (6) had a free phenolic OH. This definitely excluded the presence of an $O$ methyltyrosine residue in both compounds, and suggested a homotyrosine-containing structure as the putative structure for $\mathbf{5}$. By extension, this analysis also revealed that the homotyrosine residue in $\mathbf{6}$ is likely to contain an $N$-methyl group.

\section{Thiol Derivatization}

A micro-scale derivatization technique has been recently reported, ${ }^{39}$ which allows differentiation between MCs containing the isomeric amino acids Mdha and Dhb (dehydrobutryine, or 2-aminocrotonic acid), which have both been reported at position 7 of 
MCs. The method involves the reaction of MCs with a thiol (e.g. $\beta$-mercaptoethanol) followed by LC-MS analysis. When Mdha-containing MCs are present, the reaction is fast (several hours), but when Dhb-containing MCs are present, complete derivatization takes several days. The presence of an MdhA residue in all the MCs 1-6 from the Green Lake extract was confirmed by derivatization of the microcystins with $\beta$-mercaptoethanol and LCHRMS analysis showing complete reaction after $12 \mathrm{~h}$ (see the Supporting Information section for details).

\section{Ferintoic acids}

The ferintoic acids are a sub-class of the anabaenopeptins, cyclic hexapeptides ${ }^{40}$ that are synthesized by NRPSs. ${ }^{41}$ Anabaenopeptins contain six amino acids, five of which form a cyclic structure with an amide bond involving the $\varepsilon$-amino group on an invariant Lys residue. The sixth amino acid is attached to the Lys a-amino group through a unique ureido bridge; variants of the anabaenopeptins with L-Tyr, L-Arg, L-Phe, L-Ile, L-Glu, and L-Lys at this position have been reported. For historical reasons, anabaenopeptins with an L-Trp residue as the exocyclic amino acid are known as ferintoic acids. Two types of ferintoic acids have been described, ferintoic acid A (11), and ferintoic acid B, in which the Ile residue is replaced by Val. ${ }^{26}$ Anabaenopeptins, including the ferintoic acids, have been reported to inhibit protein phosphatase $1^{42}$ as well as proteases such as carboxypeptidase A. ${ }^{43}$

The ferintoic acid cluster (Figure 5) contained three nodes, suggesting the presence of two analogues of ferintoic acid A $(\mathbf{1 1}, \mathrm{m} / \mathrm{z}$ 867.4423) which we name here as ferintoic acid C $(\mathbf{1 2}, \mathrm{m} / z$ 899.4143) and $\mathrm{D}(\mathbf{1 3}, \mathrm{m} / \mathrm{z}$ 915.4069). The relative amounts of 11-13 (Figure 5) were estimated from the areas of the relevant peaks in the extracted-ion chromatograms. The molecular formulas of $\mathbf{1 2}\left(\mathrm{C}_{46} \mathrm{H}_{57} \mathrm{~N}_{8} \mathrm{O}_{9} \mathrm{~S}\right.$, one additional $\mathrm{S}$ atom compared ferintoic acid A) and $\mathbf{1 3}\left(\mathrm{C}_{46} \mathrm{H}_{58} \mathrm{~N}_{8} \mathrm{O}_{10} \mathrm{~S}\right.$, one additional $\mathrm{S}$ and $\mathrm{O}$ atom $)$ did not match any known anabaenopeptin analogue.

The fragmentation patterns of the new compounds were compared with that of ferintoic acid A (11) (Figure 6). The fragment ion at $m / z 591.2941\left(\mathrm{C}_{31} \mathrm{H}_{39} \mathrm{~N}_{6} \mathrm{O}_{6}{ }^{+}\right)$found in the MS/MS spectrum of $\mathbf{1 1}$ and due to the loss of amino acids 3 and 4, was also present in the MS/MS spectra of 12 and 13. This located the difference between the three compounds to be on one of these two amino acids. The ion at $\mathrm{m} / z 690.3629\left(\mathrm{C}_{36} \mathrm{H}_{48} \mathrm{~N}_{7} \mathrm{O}_{7}{ }^{+}\right)$, formed by the loss of Hty at position 4, was shifted to $\mathrm{m} / z 722.3352\left(\mathrm{C}_{36} \mathrm{H}_{48} \mathrm{~N}_{7} \mathrm{O}_{7} \mathrm{~S}^{+}\right)$for $\mathbf{1 2}$ and $\mathrm{m} / \mathrm{z} 738.3306$ $\left(\mathrm{C}_{36} \mathrm{H}_{48} \mathrm{~N}_{7} \mathrm{O}_{8} \mathrm{~S}^{+}\right)$for $\mathbf{1 3}$. Therefore, the additional atoms in $\mathbf{1 2}$ and $\mathbf{1 3}$ must be located on amino acid 3. All of the other fragment ions detected in the MS/MS spectra were fully consistent with this conclusion. Considering that substitution of methionine (or its oxidized form methionine sulfoxide) for valine has been previously observed in several anabaenopeptins, these data indicated the presence of a Met residue at position 3 in ferintoic acid C (12) and a methionine sulfoxide (MetO) residue at position 3 in ferintoic acid D (13).

\section{S-ITS rRNA Metagenomic Analysis}

The microbiome associated with the Green Lake bloom was probed using a cultivationindependent approach in order to make a preliminary survey of the identity of the cyanobacteria inhabiting this field sample. A 16S-ITS (internal transcribed spacer) rRNA

Environ Sci Technol. Author manuscript; available in PMC 2016 December 15. 
amplicon library was prepared from metagenomic DNA extracted from the collected samples. PCR products were subcloned via TOPO TA cloning and five representative plasmids were sequenced. All of the cyanobacterial sequences were identical at a $99 \%$ sequence identity threshold, and were assigned to Microcystis aeruginosa based on the top matching sequences from a BLASTn search (Table S1 in Supporting Information).

Therefore, a $M$. aeruginosa strain (named $M$. aeruginosa SEAGL14 in this paper) is the predominant cyanobacterial species present in the 2014 Green Lake bloom, and this strain is the likely producer of the MCs and ferintoic acids detected in these field samples.

\section{Signature sequences within adenylation domains and correlation with the synthesis of MC variants}

One of the most frequent structural variations in MCs is due to amino acid substitutions at position $2 .{ }^{44}$ This amino acid is selected and activated by the adenylation domain mcyBAd1. McyBAd1 fragments were amplified by PCR from the metagenomic DNA using $m c y B$-specific primers and then subcloned. Eight representative clones were sequenced that were identical at the $99 \%$ sequence identity threshold. The top matching sequences from a BLASTx search were mcyBAd1 genes from $M$. aeruginosa (Table S2 in Supporting Information). Therefore, only one genotype of mcyBAd1 (mcyBAd1_SEAGL14) was detected by PCR-based metagenomic screening, and this was clearly associated with a Microcystis species.

The nine amino acids lining the putative binding pocket of the adenylation domain ${ }^{45}$ of this variant of McyBAd1 were identified as DGWTIGAVKK. This signature sequence shared almost complete identity with the sequence (DGWTIGAVEK) of the binding pocket of the McyBAd1 genotype from a number of Microcystis strains, ${ }^{46}$ which are reported to simultaneously produce MCs containing Leu, Arg, or Tyr at position 2. It can be assumed that mcyBAd1_SEAGL14 should have a similarly relaxed substrate selectivity, and is therefore consistent with our findings here of MC variants with Leu, Phe or Tyr-related residues at position 2. It is worth noting that no MC variant with an Arg residue at position 2 was detected in the Green Lake bloom extract. This is presumably related to the fact that Glu331 is replaced by Lys331 in McyBAd1_SEAGL14. Glu331 (or Asp331) is thought to play a key role in the accommodation of basic amino acid side chains (i.e. Arg) $;{ }^{45}$ therefore, it can be argued that the presence of Lys331 instead of a negatively charged amino acid does not allow for recognition of Arg. The Glu $\rightarrow$ Lys mutation at position 331 of McyBAd1 has not been previously observed.

\section{Signature sequences within adenylation domains and correlation with the synthesis of ferintoic acids}

No specific primers for adenylation domains of anabaenopeptins (and therefore of ferintoic acids) are described in the literature; therefore, the metagenomic DNA from the Green Lake sample was amplified by PCR using more general primers, targeting highly conserved motifs in adenylation domains of NRPS. The PCR products were subcloned and six plasmids sequenced. All six were related to adenylation domains of NRPSs, however, only one (fer $\left.B \_A d\right)$ shared high similarity with AptB adenylation domains from the anabaenopeptin synthetase gene cluster (Table S2 in Supporting Information). The AptB

Environ Sci Technol. Author manuscript; available in PMC 2016 December 15. 
adenylation domain is known to recruit the amino acid residue in position 3 of the anabaenopeptins. The signature sequence of the binding pocket of FerB_Ad

(DMWFLGGAI) shares almost complete identity with the substrate specificity code (DMWFMGGVI) of AptB_Ad from the nodulapeptin synthetase cluster. ${ }^{49}$ In nodulapeptin, the AptB_Ad protein selects for Met, MetO or Ile as the substrate. Therefore, FerB_Ad is expected to be responsible for the activation of Met, MetO, Ile or Val in the production of the ferintoic acids from this Green Lake population.

\section{DISCUSSION}

Freshwater, marine, and terrestrial cyanobacteria produce a wide array of toxic metabolites, the most common of which are the MCs. ${ }^{50}$ The presence of MCs can limit the use of lakes and reservoirs for recreational activities, as drinking water reservoirs, and for irrigation. Concentrations of MC-LR are highly variable in phytoplankton communities and are greatly influenced by the composition of phytoplankton species present. The World Health Organisation (WHO) has set a provisional guideline value for MC-LR of $1.0 \mu \mathrm{g} / \mathrm{L}$ in drinking water. More generally, WHO established a level of 100,000 cyanobacterial cells/mL (equivalent to approximately $50 \mu \mathrm{g}$ chlorophyll-a/L if cyanobacteria dominate) as a guideline value for a moderate health alert in recreational waters. ${ }^{50}$ These provisions for adequate public warnings are the only short-term measure to avoid large scale intoxications and allergies. We are evaluating the feasibility of early detection of cyanobacterial blooms using similar remote and proximal sensing tools as those used to monitor contamination of surface waters. ${ }^{51}$

Nutrient enrichment has been proved to be the most important factor responsible for cyanobacterial blooms, ${ }^{10}$ even if this is a topic still opened for further studies. Similarly, our knowledge is fragmentary concerning the structures and amounts of cyanotoxins produced, the fate of these cyanotoxins in the food chain, and the influence of human activities on these events. Even if national authorities are generally aware of the MC problem, present regulations are generally at the provisional state and will need to change as knowledge increases on the structure, distribution, and toxicology of MCs.

A general method for the rapid detection of known or novel (and potentially more toxic) cyanotoxins is an urgent need to properly manage cyanobacterial blooms, and should be considered in health control programs at the private, municipal, and state levels. The large structural variability of cyanotoxins, and the frequent occurrence of new congeners, makes the problem of developing such a method a challenging one. The Green Lake bloom is illustrative in this respect: the new MC-MhtyR was by no means a minor compound, and comprised about half of the total MC content in the collected samples. In contrast, MC-LR, the only MC whose concentration is considered in WHO guidelines, represented only about $7 \%$ of the total MCs. Similarly, the new ferintoic acids C and D predominated over the known ferintoic acid A.

Currently, cyanotoxins are predominately monitored using reversed-phase HPLC combined with MS and MS/MS. The current MS-based methods are fast and sensitive, but require the availability of standards, or rely on assumptions concerning the structures of the analyzed 
MCs. This approach can fail in the identification of new cyanotoxins. For example, the most general method which can be used for the MS/MS identification of MCs by MS/MS relies on the fragment peak at $\mathrm{m} / z 135$ arising from side-chain fragmentation of the Adda residue. While this residue is generally conserved in MCs, some examples of MCs are known in which a free $\mathrm{OH}$ or an OAc group replaces the OMe group in Adda. ${ }^{52}$ Such MCs or others with a modification to the Adda residue would not be identified by this MS/MS method.

This combined high-resolution LC-MS and automated molecular networking data analysis approach may be used for the rapid identification of both known as well as new variants of the MCs. The method does require a library of reference MS/MS spectra, but due to its inherent capacity to show the similarities between structurally related molecules, can be highly effective to identify even previously undescribed variants. Moreover, even though the GNPS website has only a few cyanotoxins at the present time, it was highly effective in helping to identify these cyanotoxins in the Green Lake bloom. It can be anticipated that future depositions to GNPS of cyanotoxin high resolution MS/MS spectra will further improve the effectiveness of the method. We are currently working to build such a library using both standards and the cyanotoxins present in cultured and field samples.

In this study, we were able to determine the putative structure of the new MC-MhtyR (6) even though the compound was present in the sample in insufficient quantities for NMR analysis. This took advantage of a microscale methylation reaction with (trimethylsilyl)diazomethane that was used here for the first time in the structural analysis of a natural product.

The predominant cyanobacterium in the 2014 Green Lake bloom was identified as a strain of Microcystis aeruginosa. Fragments of the putative adenylation domains belonging to the microcystin and ferintoic acid gene clusters were also identified. Their sequences, especially those that determine substrate selectivity, matched well with the structures of the identified cyanotoxins from the bloom sample. Therefore, it appears very likely that the fragments found in the metagenomic DNA from the Green Lake blooms are indeed part of the microcystin and ferintoic acid gene clusters.

\section{Supplementary Material}

Refer to Web version on PubMed Central for supplementary material.

\section{Acknowledgments}

This work was funded by the European Union's Seventh Framework Programme (FP7) 2007-2013 under Grant Agreement No. 311848 (Bluegenics), and by Regione Campania under POR Campania FESR 2007-2013 - O.O. 2.1 (FarmaBioNet), and partially funded by NIH R01 GM107550 to LG and WHG.

We are grateful to Prof. Daniel Jaffe (University of Washington Seattle) and Prof. Paul Bishop (University of Rhode Island) for their contribution in the sampling phase and for their encouragement and support. 


\section{References}

1. Pettit GR, Kamano Y, Herald CL, Tuinman AA, Boettner FE, Kizu H, Schmidt JM, Baczynskyj L, Tomer KB, Bontems RJ. The isolation and structure of a remarkable marine animal antineoplastic constituent: dolastatin 10. J Am Chem Soc. 1987; 109:6883-6885.

2. Schwartz RE, Hirsch CF, Sesin DF, Flor JE, Chartrain M, Fromtling RE, Harris GH, Salvatore MJ, Liesch JM, Yudin K. Pharmaceuticals from cultured algae. J Ind Microbiol. 1990; 5:113-123.

3. Gerwick WH, Proteau PJ, Nagle DG, Hamel E, Blokhin A, Slate DL. Structure of curacin A, a novel antimitotic, antiproliferative, and brine shrimp toxic natural product from the marine cyanobacterium Lyngbya majuscula. J Org Chem. 1994; 59:1243-1245.

4. Dixit RB, Suseela MR. Cyanobacteria: potential candidates for drug discovery. Antonie van Leeuwenhoek. 2013; 103:947-61. [PubMed: 23532410]

5. Della Sala G, Hochmuth T, Costantino V, Teta R, Gerwick W, Gerwick L, Piel J, Mangoni A. Polyketide genes in the marine sponge Plakortis simplex: a new group of mono-modular type I polyketide synthases from sponge symbionts. Environ Microbiol Rep. 2013; 5:809-818. [PubMed: 24249289]

6. Della Sala G, Hochmuth T, Teta R, Costantino V, Mangoni A. Polyketide synthases in the microbiome of the marine sponge Plakortis halichondrioides: a metagenomic update. Mar Drugs. 2014; 12:5425-5440. [PubMed: 25405856]

7. Luesch H, Moore RE, Paul VJ, Mooberry SL, Corbett TH. Isolation of dolastatin 10 from the marine cyanobacterium Symploca species VP642 and total stereochemistry and biological evaluation of its analogue symplostatin 1. J Nat Prod. 2001; 64:907-910. [PubMed: 11473421]

8. Esposito G, Teta R, Miceli R, Ceccarelli LS, Della Sala G, Camerlingo R, Irollo E, Mangoni A, Pirozzi G, Costantino V. Isolation and assessment of the in vitro anti-tumor activity of smenothiazole A and B, chlorinated thiazole-containing peptide/polyketides from the caribbean sponge, Smenospongia aurea. Mar Drugs. 2015; 13:444-459. 16. [PubMed: 25603342]

9. Edwards DJ, Marquez BL, Nogle LM, McPhail K, Goeger DE, Roberts MA, Gerwick WH. Structure and biosynthesis of the jamaicamides, new mixed polyketide-peptide neurotoxins from the marine cyanobacterium Lyngbya majuscula. Chem Biol. 2004; 11:817-823. [PubMed: 15217615]

10. Carvalho L, McDonald C, de Hoyos C, Mischke U, Phillips G, Borics G, Poikane S, Skjelbred B, Solheim AL, Van Wichelen J, Cardoso AC. Sustaining recreational quality of European lakes: minimizing the health risks from algal blooms through phosphorus control. J Appl Ecol. 2013; 50:315-323.

11. Digamber Rao B, Babu Ramesh M, Ellaswamy N. Cyanotoxins and their potential applications. A review. Nat Environ Poll Tech. 2015; 14:203-209.Rao PV, Gupta N, Bhaskar AS, Jayaraj R. Toxins and bioactive compounds from cyanobacteria and their implication on human health. J Environ Biol. 2002; 23:215-224. [PubMed: 12597562]

12.

EPA-190-R-15-001, United States Environmental Agency, Fiscal Year 2016; www.epa.gov/ocfo.

13. Watrous J, Roach P, Alexandrov T, Heath BS, Yang JY, Kersten RD, van der Voort M, Pogliano K, Gross H, Raaijmakers JM, Moore BS, Laskin J, Bandeira N, Dorrestein PC. Mass spectral molecular networking of living microbial colonies. Proc Natl Acad Sci US A. 2012; 109:E1743E1752.

14. Crowley BM, Mori Y, McComas CC, Tang D, Boger DL. Total Synthesis of the Ristocetin Aglycon. J Am Chem Soc. 2004; 126:4310-4317. [PubMed: 15053621]

15. ProteoWizard Software Foundation. http://proteowizard.sourceforge.net/tools.shtml

16. UCSD Computational Mass Spectrometer Website. http://gnps.ucsd.edu/

17. Cytoscape Software. http://www.cytoscape.org/

18. Cytoscape Software FM3 plug-in. http://apps.cytoscape.org/apps/fm3

19. Boutte C, Grubisic S, Balthasart P, Wilmotte A. Testing of primers for the study of cyanobacterial molecular diversity by DGGE. J Microbiol Meth. 2006; 65:542-550. 
20. Janse I, Meima M, Kardinaal WEA, Zwart G. High resolution differentiation of cyanobacteria by using rRNA internal transcribed spacer denaturing gradient gel electrophoresis. Appl Environ Microbiol. 2003; 69:6634-6643. [PubMed: 14602623]

21. Brett NA, Dittmann E, Rouhiainen LR, Bass A, Schaub V, Sivonen K, Borner T. Nonribosomal Peptide Synthesis and Toxigenicity of Cyanobacteria. J Bacteriol. 1999; 181:4089-4097. [PubMed: 10383979]

22. Cole JR, Wang Q, Cardenas E, Fish J, Chai B, Farris RJ, Kulam-Syed-Mohideen AS, McGarrell DM, Marsh T, Garrity GM, Tiedje JM. The Ribosomal Database Project: improved alignments and new tools for rRNA analysis. Nucleic Acids Res. 2009; 37(Database issue):D141-145. [PubMed: 19004872]

23. Altschul SF, Madden TL, Schaffer AA, Zhang J, Zhang Z, Miller W, Lipman DJ. Gapped BLAST and PSI-BLAST: a new generation of protein database search programs. Nucl Acids Res. 1997; 25:3389-3402. [PubMed: 9254694]

24. Yang JY, Sanchez LM, Rath CM, Liu X, Boudreau PD, Bruns N, Glukhov E, Wodtke A, de Felicio R, Fenner A, Wong WR, Linington RG, Zhang L, Debonsi HM, Gerwick WH, Dorrestein PC. Molecular Networking as a Dereplication Strategy. J Nat Prod. 2013; 76:1686-1699. [PubMed: 24025162]

25. Carmichael WW, Beasley V, Bunner DL, Eloff JN, Falconer I, Gorham P, Harada K, Krishnamurthy T, Yu MJ, Moore RE. Naming of cyclic heptapeptide toxins of cyanobacteria (bluegreen algae). Toxicon. 1988; 26:971-973. [PubMed: 3149803]

26. Williams DE, Craig M, Holmes CFB, Andersen RJ. Ferintoic acids A and B, new cyclic hexapeptides from the freshwater cyanobacterium Microcystis aeruginosa. J Nat Prod. 1996; 59:570-575.

27. Portmann C, Blom JF, Gademann K, Juttner F. Aerucyclamides A and B: isolation and synthesis of toxic ribosomal heterocyclic peptides from the cyanobacterium Microcystis aeruginosa PCC 7806. J Nat Prod. 2008; 71:1193-1196. [PubMed: 18558743]

28. Tillet D, Dittman E, Erhard M, Von Dorhen H, Borner T, Neilan BA. Structural organization of microcystin biosynthesis in Microcystis aeruginosa PCC7806: an integrated peptide-polyketide synthetase system. Chem Biol. 2000; 7:753-764. [PubMed: 11033079]

29. Van Wagoner RM, Drummond AK, Wright JLC. Biogenetic diversity of cyanobacterial metabolites. Adv Appl Microbiol. 2007; 61:89-217. [PubMed: 17448789]

30. Puddick, J. PhD Thesis. University of Waikato; Hamilton, New Zealand: 2013. Spectroscopic Investigations of oligopeptides from aquatic cyanobacteria: Characterisation of new oligopeptides, development of microcystin quantification tools and investigations into microcystin production. http://researchcommons. waikato.ac.nz/handle/10289/7289

31. Mackintosh C, Beattie KA, Klumpp S, Cohen P, Codd GA. Cyanobacterial microcystin-LR is a potent and specific inhibitor of protein phosphatases 1 and $2 \mathrm{~A}$ from both mammals and higher plants. FEBS Lett. 1990; 264:187-192. [PubMed: 2162782]

32. Carmichael WW. Cyanobacteria secondary metabolites - the cyanotoxins. J Appl Bacteriol. 1992; 72:445-459. [PubMed: 1644701]

33. Liu WT, Ng J, Meluzzi D, Bandeira N, Gutierrez M, Simmons TL, Schultz AW, Linington RG, Moore BS, Gerwick WH, Pevzner PA, Dorrestein PC. Interpretation of Tandem Mass Spectra Obtained from Cyclic Nonribosomal Peptides. Anal Chem. 2009; 81:4200-4209. [PubMed: 19413302]

34. Mayumi T, Kato H, Imanishi S, Kawasaki Y, Hasegawa M, Harada K. Structural characterization of microcystins by LC/MS/MS under ion trap conditions. J Antibiot. 2006; 59:710-719. [PubMed: 17256470]

35. Benke PI, Vinay Kumar MCS, Panc D, Swarup S. A mass spectrometry-based unique fragment approach for the identification of microcystins. Analyst. 2015; 140:1198-1206. [PubMed: 25525642]

36. Namikoshi M, Sun FB, Choi W, Rinehart KL, Carmichael WW, Evans WR, Beasley VR. Seven More Microcystins from Homer Lake Cells: Application of the General Method for Structure Assignment of Peptides Containing a, $\beta$-Dehydroamino Acid Unit(s). J Org Chem. 1995; 60:36713679 . 
37. Sano T, Takagi H, Nagano K, Nishikawa M, Kaya K. Accurate LC-MS analyses for microcystins using per-15N-labeled microcystins. Anal Bioanal Chem. 2011; 399:2511-2516. [PubMed: 21221535]

38. Medina RA, Goeger DE, Hills P, Mooberry SL, Huang N, Romero LI, Ortega-Barria E, Gerwick WH, McPhail KL. Coibamide A, a Potent Antiproliferative Cyclic Depsipeptide from the Panamanian Marine Cyanobacterium Leptolyngbya sp. J Am Chem Soc. 2008; 130:6324-6325. [PubMed: 18444611]

39. Miles CO, Sandvik M, Nonga HE, Rundberget T, Wilkins AL, Rise F, Ballot A. Thiol derivatization for LC-MS identification of microcystins in complex matrices. Environ Sci Technol. 2012; 46:8937-8944. [PubMed: 22834560]

40. Harada K, Fujii K, Shimada T, Suzuki M, Sano H, Adachi K, Carmichael WW. Two cyclic peptides, anabaenopeptins, a third group of bioactive compounds from the cyanobacterium Anabaena flos-aquae NRC 525-17. Tetrahedron Lett. 1995; 36:1511-1514.

41. Fujii K, Sivonen K, Nakano T, Harada KI. Structural elucidation of cyanobacterial peptides encoded by peptide synthetase gene in Anabaena species. Tetrahedron. 2002; 58:6863-6871.

42. Gkelis S, Lanaras T, Sivonen K. The presence of microcystins and other cyanobacterial bioactive peptides in aquatic fauna collected from Greek freshwaters. Aquat Toxicol. 2006; 78:32-41. [PubMed: 16540185]

43. Itou Y, Suzuki S, Ishida K, Murakami M. Anabaenopeptins G and H, potent carboxypeptidase A inhibitors from the cyanobacterium Oscillatoria agardhii (NIES-595). Bioorg Med Chem Lett. 1999; 9:1243-1246. [PubMed: 10340607]

44. Kruger T, Christian B, Luckas B. Development of an analytical method for the unambiguous structure elucidation of cyclic peptides with special appliance for hepatotoxic desmethylated microcystins. Toxicon. 2009; 54:302-312. [PubMed: 19397919]

45. Stachelhaus T, Mootz HD, Marahiel MA. The specificity-conferring code of adenylation domains in nonribosomal peptide synthetases. Chem Biol. 1999; 6:493-505. [PubMed: 10421756]

46. Tooming-Klunderud A, Fewer DP, Rohrlack T, et al. Evidence for positive selection acting on microcystin synthetase adenylation domains in three cyanobacterial genera. BMC Evolutionary Biology. 2008; 8:256. [PubMed: 18808704]

47. Conti E, Stachelhaus T, Marahiel MA, Brick P. Structural basis for the activation of phenylalanine in the nonribosomal biosynthesis of gramicidin S. EMBO. 1997; 16:4174-4183.

48. Mikalsen BG, Boison OM, Skulberg J, Fastner W, Davies TM, et al. Natural variation in the microcystin synthetase operon mcy ABC and impact on microcystin production in Microcystis Strains. J Bacteriol. 2003; 185:2774-2785. [PubMed: 12700256]

49. Rouhiainen L, Jokela J, Fewer DP, Urmann M, Sivonen K. Two Alternative Starter Modules for the Non-Ribosomal Biosynthesis of Specific Anabaenopeptin Variants in Anabaena (Cyanobacteria). Chem Biol. 2010; 17:265-273. [PubMed: 20338518]

50. Guidelines for safe recreational water environments. Volume 1: Coastal and fresh waters. http:// www.who.int/water_sanitation_health/bathing/srwelexecsum/en/index6.html\#

51. Lega M, Kosmatka J, Ferrara C, Russo F, Napoli RMA, Persechino G. Using Advanced Aerial Platforms and Infrared Thermography to Track Environmental Contamination. Environ Forensics (Taylor \& Francis). 2012; 13:332-338.

52. Oksanen I, Jokela J, Fewer DP, Wahlsten M, Rikkinen J, Sivonen K. Discovery of rare and highly toxic microcystins from lichen-associated cyanobacterium Nostoc sp. strain IO-102- I. Appl Environ Microbiol. 2004; 70:5756-5763. [PubMed: 15466511] 

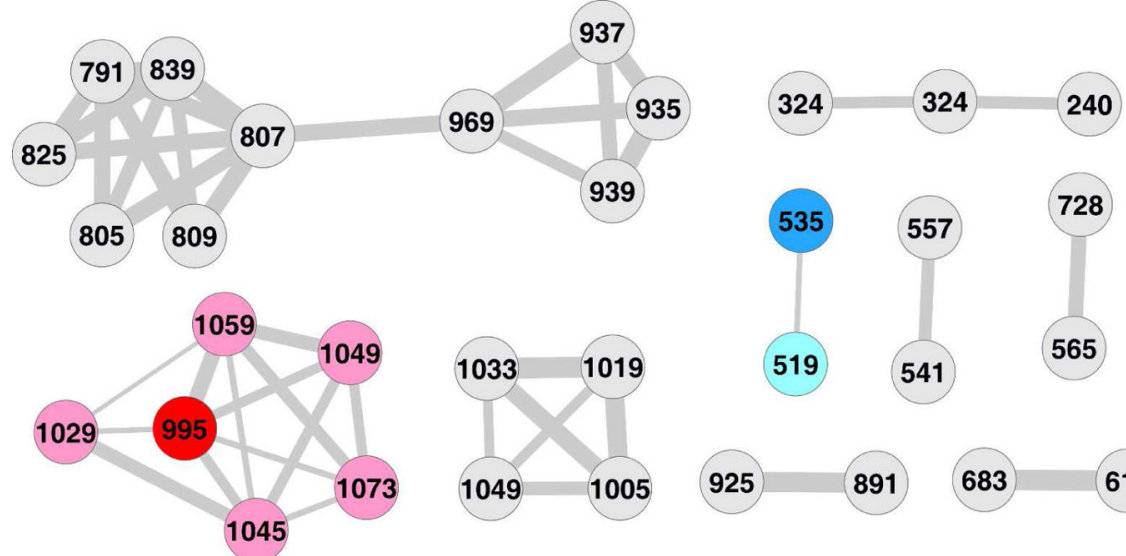

925

891

683

613
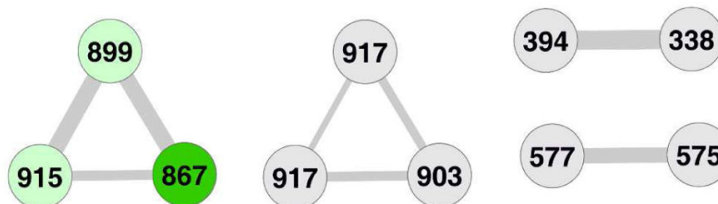

microcystin-LR ( $\mathrm{m} / \mathrm{z}$ 995) microcystin analogues ferintoic acid $\mathrm{A}(\mathrm{m} / \mathrm{z}$ 867)

ferintoic acid analogues

$577 \quad 575 \square$ aerucyclamide A $(\mathrm{m} / \mathrm{z} 535)$ unknown

Figure 1.

Molecular network from Seattle Green Lake organic extract with a cosine similarity score cutoff of 0.60 . Nodes are labeled with parent $\mathrm{m} / \mathrm{z}$ ratio; edge thickness is related to cosine similarity score. 


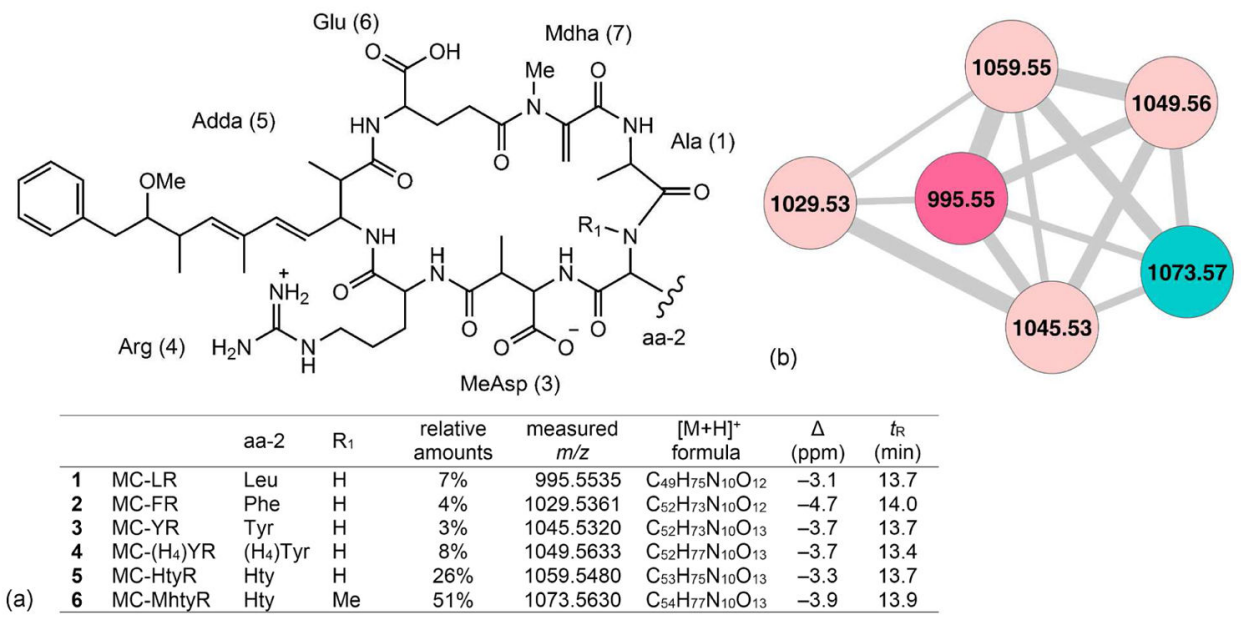

Figure 2.

(a) Structures of MC congeners found in Green Lake, Seattle. (b) The MC cluster from the Green Lake extract. Adda is 3-amino-9-methoxy-2,6,8-trimethyl-10-phenyl-4,6-decadienoic acid; MeAsp is $\beta$-methyl aspartic acid; Mdha is $N$-methyldehydroalanine; $\left(\mathrm{H}_{4}\right)$ Tyr is $1,2,3,4-$ tetrahydrotyrosine; Htyr is homotyrosine; Mhtyr is $N$-methylhomotyrosine. 


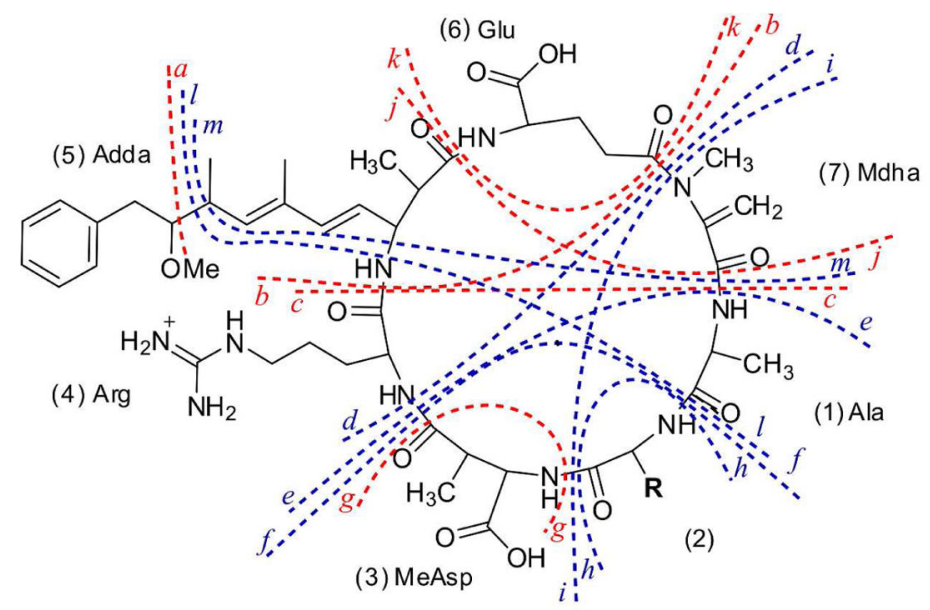

\begin{tabular}{|c|c|c|c|c|c|c|}
\hline $\begin{array}{l}\text { fragment } \\
\text { ion }\end{array}$ & MC-LR (1) & MC-FR (2) & MC-YR (3) & $\mathrm{MC}-\left(\mathrm{H}_{4}\right) \mathrm{YR}(4)$ & MC-HtyR (5) & MC-MhtyR (6) \\
\hline$[\mathrm{M}+\mathrm{H}]^{+}$ & $\begin{array}{c}995.5535 \\
\mathrm{C}_{49} \mathrm{H}_{75} \mathrm{~N}_{10} \mathrm{O}_{12}{ }^{+}\end{array}$ & $\begin{array}{c}1029.5361 \\
\mathrm{C}_{52} \mathrm{H}_{73} \mathrm{~N}_{10} \mathrm{O}_{12}{ }^{+}\end{array}$ & $\begin{array}{c}1045.5320 \\
\mathrm{C}_{52} \mathrm{H}_{73} \mathrm{~N}_{10} \mathrm{O}_{13}{ }^{+}\end{array}$ & $\begin{array}{c}1049.5633 \\
\mathrm{C}_{52} \mathrm{H}_{77} \mathrm{~N}_{10} \mathrm{O}_{13}\end{array}$ & $\begin{array}{c}1059.5480 \\
\mathrm{C}_{53} \mathrm{H}_{75} \mathrm{~N}_{10} \mathrm{O}_{13}{ }^{+}\end{array}$ & $\begin{array}{c}1073.5630 \\
\mathrm{C}_{54} \mathrm{H}_{77} \mathrm{~N}_{10} \mathrm{O}_{13}{ }^{+}\end{array}$ \\
\hline a & $\begin{array}{c}861.4803 \\
\mathrm{C}_{40} \mathrm{H}_{65} \mathrm{~N}_{10} \mathrm{O}_{11}{ }^{+}\end{array}$ & $\begin{array}{c}895.4702 \\
\mathrm{C}_{43} \mathrm{H}_{63} \mathrm{~N}_{10} \mathrm{O}_{11}{ }^{+}\end{array}$ & $\begin{array}{c}911.4591 \\
\mathrm{C}_{43} \mathrm{H}_{63} \mathrm{~N}_{10} \mathrm{O}_{12}{ }^{+}\end{array}$ & $\begin{array}{c}915.4967 \\
\mathrm{C}_{43} \mathrm{H}_{67} \mathrm{~N}_{10} \mathrm{O}_{12}{ }^{+}\end{array}$ & $\begin{array}{c}925.4768 \\
\mathrm{C}_{44} \mathrm{H}_{65} \mathrm{~N}_{10} \mathrm{O}_{12}{ }^{+}\end{array}$ & $\begin{array}{c}939.4926 \\
\mathrm{C}_{45} \mathrm{H}_{67} \mathrm{~N}_{10} \mathrm{O}_{12}{ }^{+}\end{array}$ \\
\hline$b$ & $\begin{array}{c}553.3073 \\
\mathrm{C}_{24} \mathrm{H}_{41} \mathrm{~N}_{8} \mathrm{O}_{7}^{+}\end{array}$ & $\begin{array}{c}587.2954 \\
\mathrm{C}_{27} \mathrm{H}_{39} \mathrm{~N}_{8} \mathrm{O}_{7}^{+}\end{array}$ & $\begin{array}{c}603.2861 \\
\mathrm{C}_{27} \mathrm{H}_{39} \mathrm{~N}_{8} \mathrm{O}_{8}^{+}\end{array}$ & $\begin{array}{c}607.3217 \\
\mathrm{C}_{27} \mathrm{H}_{43} \mathrm{~N}_{8} \mathrm{O}_{8}^{+}\end{array}$ & $\begin{array}{c}617.3033 \\
\mathrm{C}_{28} \mathrm{H}_{41} \mathrm{~N}_{8} \mathrm{O}_{8}^{+}\end{array}$ & $\begin{array}{c}631.3190 \\
\mathrm{C}_{29} \mathrm{H}_{43} \mathrm{~N}_{8} \mathrm{O}_{8}^{+}\end{array}$ \\
\hline c & $\begin{array}{c}470.2704 \\
\mathrm{C}_{20} \mathrm{H}_{36} \mathrm{~N}_{7} \mathrm{O}_{6}{ }^{+}\end{array}$ & $\begin{array}{c}504.2580 \\
\mathrm{C}_{23} \mathrm{H}_{34} \mathrm{~N}_{7} \mathrm{O}_{6}{ }^{+}\end{array}$ & $\begin{array}{c}520.2494 \\
\mathrm{C}_{23} \mathrm{H}_{34} \mathrm{~N}_{7} \mathrm{O}_{7}^{+}\end{array}$ & $\begin{array}{c}524.2840 \\
\mathrm{C}_{23} \mathrm{H}_{38} \mathrm{~N}_{7} \mathrm{O}_{7}^{+}\end{array}$ & $\begin{array}{c}534.2662 \\
\mathrm{C}_{24} \mathrm{H}_{36} \mathrm{~N}_{7} \mathrm{O}_{7}^{+}\end{array}$ & $\begin{array}{c}548.2818 \\
\mathrm{C}_{25} \mathrm{H}_{38} \mathrm{~N}_{7} \mathrm{O}_{7}^{+}\end{array}$ \\
\hline$d$ & $\begin{array}{c}599.3529 \\
\mathrm{C}_{31} \mathrm{H}_{47} \mathrm{~N}_{6} \mathrm{O}_{6}{ }^{+}\end{array}$ & $\begin{array}{c}599.3568 \\
\mathrm{C}_{31} \mathrm{H}_{47} \mathrm{~N}_{6} \mathrm{O}_{6}{ }^{+}\end{array}$ & $\begin{array}{c}599.3529 \\
\mathrm{C}_{31} \mathrm{H}_{47} \mathrm{~N}_{6} \mathrm{O}_{6}^{+}\end{array}$ & $\begin{array}{c}599.3570 \\
\mathrm{C}_{31} \mathrm{H}_{47} \mathrm{~N}_{6} \mathrm{O}_{6}{ }^{+}\end{array}$ & $\begin{array}{c}599.3542 \\
\mathrm{C}_{31} \mathrm{H}_{47} \mathrm{~N}_{6} \mathrm{O}_{6}{ }^{+}\end{array}$ & $\begin{array}{c}599.3542 \\
\mathrm{C}_{31} \mathrm{H}_{47} \mathrm{~N}_{6} \mathrm{O}_{6}{ }^{+}\end{array}$ \\
\hline e & $\begin{array}{c}682.3899 \\
\mathrm{C}_{35} \mathrm{H}_{52} \mathrm{~N}_{7} \mathrm{O}_{7}^{+}\end{array}$ & $\begin{array}{c}682.3944 \\
\mathrm{C}_{35} \mathrm{H}_{52} \mathrm{~N}_{7} \mathrm{O}_{7}^{+}\end{array}$ & $\begin{array}{c}682.3899 \\
\mathrm{C}_{35} \mathrm{H}_{52} \mathrm{~N}_{7} \mathrm{O}_{7}^{+}\end{array}$ & $\begin{array}{c}682.3945 \\
\mathrm{C}_{35} \mathrm{H}_{52} \mathrm{~N}_{7} \mathrm{O}_{7}^{+}\end{array}$ & $\begin{array}{c}682.3913 \\
\mathrm{C}_{35} \mathrm{H}_{52} \mathrm{~N}_{7} \mathrm{O}_{7}^{+}\end{array}$ & $\begin{array}{c}682.3915 \\
\mathrm{C}_{35} \mathrm{H}_{52} \mathrm{~N}_{7} \mathrm{O}_{7}^{+}\end{array}$ \\
\hline$f$ & $\begin{array}{c}753.4269 \\
\mathrm{C}_{38} \mathrm{H}_{57} \mathrm{~N}_{8} \mathrm{O}_{8}^{+}\end{array}$ & $\begin{array}{c}753.4319 \\
\mathrm{C}_{38} \mathrm{H}_{57} \mathrm{~N}_{8} \mathrm{O}_{8}{ }^{+}\end{array}$ & $\begin{array}{c}753.4266 \\
\mathrm{C}_{38} \mathrm{H}_{57} \mathrm{~N}_{8} \mathrm{O}_{8}{ }^{+}\end{array}$ & $\begin{array}{c}753.4315 \\
\mathrm{C}_{38} \mathrm{H}_{57} \mathrm{~N}_{8} \mathrm{O}_{8}{ }^{+}\end{array}$ & $\begin{array}{c}753.4284 \\
\mathrm{C}_{38} \mathrm{H}_{57} \mathrm{~N}_{8} \mathrm{O}_{8}^{+}\end{array}$ & $\begin{array}{c}753.4289 \\
\mathrm{C}_{38} \mathrm{H}_{57} \mathrm{~N}_{8} \mathrm{O}_{8}^{+}\end{array}$ \\
\hline$g$ & $\begin{array}{c}866.5109 \\
\mathrm{C}_{44} \mathrm{H}_{68} \mathrm{~N}_{9} \mathrm{O}_{9}^{+}\end{array}$ & $\begin{array}{c}900.5008 \\
\mathrm{C}_{47} \mathrm{H}_{66} \mathrm{~N}_{9} \mathrm{O}_{9}{ }^{+}\end{array}$ & $\begin{array}{c}916.4899 \\
\mathrm{C}_{47} \mathrm{H}_{66} \mathrm{~N}_{9} \mathrm{O}_{10}{ }^{+}\end{array}$ & $\begin{array}{c}920.5272 \\
\mathrm{C}_{47} \mathrm{H}_{70} \mathrm{~N}_{9} \mathrm{O}_{10}{ }^{+}\end{array}$ & $\begin{array}{c}930.5075 \\
\mathrm{C}_{48} \mathrm{H}_{68} \mathrm{~N}_{9} \mathrm{O}_{10}{ }^{+}\end{array}$ & $\begin{array}{c}944.5231 \\
\mathrm{C}_{49} \mathrm{H}_{70} \mathrm{~N}_{9} \mathrm{O}_{10}{ }^{+}\end{array}$ \\
\hline$h$ & $\begin{array}{c}882.4693 \\
\mathrm{C}_{43} \mathrm{H}_{64} \mathrm{~N}_{9} \mathrm{O}_{11}{ }^{+}\end{array}$ & $\begin{array}{c}882.4753 \\
\mathrm{C}_{43} \mathrm{H}_{64} \mathrm{~N}_{9} \mathrm{O}_{11}{ }^{+}\end{array}$ & $\mathrm{C}_{43} \mathrm{H}_{64} \mathrm{H}_{6} \mathrm{~N}_{9} \mathrm{O}_{11}{ }^{+}$ & $\mathrm{C}_{43} \mathrm{H}_{64} \mathrm{H}_{64} \mathrm{~N}_{9} \mathrm{O}_{11}{ }^{+}$ & $\begin{array}{c}882.4714 \\
\mathrm{C}_{43} \mathrm{H}_{64} \mathrm{~N}_{9} \mathrm{O}_{11}{ }^{+}\end{array}$ & $\mathrm{C}_{43}^{882.4709} \mathrm{H}_{64} \mathrm{~N}_{9} \mathrm{O}_{11}{ }^{+}$ \\
\hline$i$ & $\begin{array}{c}728.3953 \\
\mathrm{C}_{36} \mathrm{H}_{54} \mathrm{~N}_{7} \mathrm{O}_{9}^{+}\end{array}$ & $\mathrm{C}_{36} \mathrm{H}_{54} \mathrm{~N}_{7} \mathrm{O}_{9}{ }^{+}$ & $\mathrm{C}_{36} \begin{array}{c}728.3950 \\
\mathrm{H}_{54} \mathrm{~N}_{7} \mathrm{O}_{9}^{+}\end{array}$ & $\begin{array}{c}728.4000 \\
\mathrm{C}_{36} \mathrm{H}_{54} \mathrm{~N}_{7} \mathrm{O}_{9}^{+}\end{array}$ & $\mathrm{C}_{36}^{728.3969} \mathrm{H}_{54} \mathrm{~N}_{7} \mathrm{O}_{9}^{+}$ & $\begin{array}{c}728.3969 \\
\mathrm{C}_{36} \mathrm{H}_{54} \mathrm{~N}_{7} \mathrm{O}_{9}^{+}\end{array}$ \\
\hline j & $\begin{array}{c}783.4740 \\
\mathrm{C}_{40} \mathrm{H}_{63} \mathrm{~N}_{8} \mathrm{O}_{8}{ }^{+}\end{array}$ & $\begin{array}{c}817.4633 \\
\mathrm{C}_{43} \mathrm{H}_{61} \mathrm{~N}_{8} \mathrm{O}_{8}{ }^{+}\end{array}$ & $\begin{array}{c}833.4529 \\
\mathrm{C}_{43} \mathrm{H}_{61} \mathrm{~N}_{8} \mathrm{O}_{9}^{+}\end{array}$ & $\begin{array}{c}837.4896 \\
\mathrm{C}_{43} \mathrm{H}_{65} \mathrm{~N}_{8} \mathrm{O}_{9}{ }^{+}\end{array}$ & $\begin{array}{c}847.4701 \\
\mathrm{C}_{44} \mathrm{H}_{63} \mathrm{~N}_{8} \mathrm{O}_{9}{ }^{+}\end{array}$ & $\begin{array}{c}861.4859 \\
\mathrm{C}_{45} \mathrm{H}_{65} \mathrm{~N}_{8} \mathrm{O}_{9}^{+}\end{array}$ \\
\hline$k$ & $\begin{array}{c}866.5109 \\
\mathrm{C}_{44} \mathrm{H}_{68} \mathrm{~N}_{9} \mathrm{O}_{9}^{+}\end{array}$ & $\begin{array}{c}900.5008 \\
\mathrm{C}_{47} \mathrm{H}_{66} \mathrm{~N}_{9} \mathrm{O}_{9}^{+}\end{array}$ & $\begin{array}{c}916.4899 \\
\mathrm{C}_{47} \mathrm{H}_{66} \mathrm{~N}_{9} \mathrm{O}_{10}{ }^{+}\end{array}$ & $\begin{array}{c}920.5272 \\
\mathrm{C}_{47} \mathrm{H}_{70} \mathrm{~N}_{9} \mathrm{O}_{10}{ }^{+}\end{array}$ & $\begin{array}{c}930.5075 \\
\mathrm{C}_{48} \mathrm{H}_{68} \mathrm{~N}_{9} \mathrm{O}_{10}{ }^{+}\end{array}$ & $\begin{array}{c}944.5231 \\
\mathrm{C}_{49} \mathrm{H}_{70} \mathrm{~N}_{9} \mathrm{O}_{10}+\end{array}$ \\
\hline 1 & $\begin{array}{c}446.2271 \\
\mathrm{C}_{23} \mathrm{H}_{32} \mathrm{~N}_{3} \mathrm{O}_{6}{ }^{+}\end{array}$ & $\begin{array}{c}446.2301 \\
\mathrm{C}_{23} \mathrm{H}_{32} \mathrm{~N}_{3} \mathrm{O}_{6}{ }^{+}\end{array}$ & $\frac{446.2267}{\mathrm{C}_{23} \mathrm{H}_{32} \mathrm{~N}_{3} \mathrm{O}_{6}^{+}}$ & $\begin{array}{c}446.2298 \\
\mathrm{C}_{23} \mathrm{H}_{32} \mathrm{~N}_{3} \mathrm{O}_{6}^{+}\end{array}$ & $\mathrm{C}_{23} \mathrm{H}_{32} \mathrm{~N}_{3} \mathrm{O}_{6}{ }^{+}$ & $\begin{array}{c}446.2278 \\
\mathrm{C}_{23} \mathrm{H}_{32} \mathrm{~N}_{3} \mathrm{O}_{6}^{+}\end{array}$ \\
\hline$m$ & $\begin{array}{c}375.1903 \\
\mathrm{C}_{20} \mathrm{H}_{27} \mathrm{~N}_{2} \mathrm{O}_{5}{ }^{+}\end{array}$ & $\begin{array}{c}375.1926 \\
\mathrm{C}_{20} \mathrm{H}_{27} \mathrm{~N}_{2} \mathrm{O}_{5}{ }^{+}\end{array}$ & $\begin{array}{c}375.1902 \\
\mathrm{C}_{20} \mathrm{H}_{27} \mathrm{~N}_{2} \mathrm{O}_{5}^{+}\end{array}$ & $\begin{array}{c}375.1929 \\
\mathrm{C}_{20} \mathrm{H}_{27} \mathrm{~N}_{2} \mathrm{O}_{5}{ }^{+}\end{array}$ & $\begin{array}{c}375.1910 \\
\mathrm{C}_{20} \mathrm{H}_{27} \mathrm{~N}_{2} \mathrm{O}_{5}{ }^{+}\end{array}$ & $\begin{array}{c}375.1910 \\
\mathrm{C}_{20} \mathrm{H}_{27} \mathrm{~N}_{2} \mathrm{O}_{5}{ }^{+}\end{array}$ \\
\hline
\end{tabular}

Figure 3.

High-resolution MS/MS fragmentations of MCs. Fragments which are mass shifted and therefore contain the variable amino acid residue are labeled in red, while the non-shifting fragments are labeled in blue. 

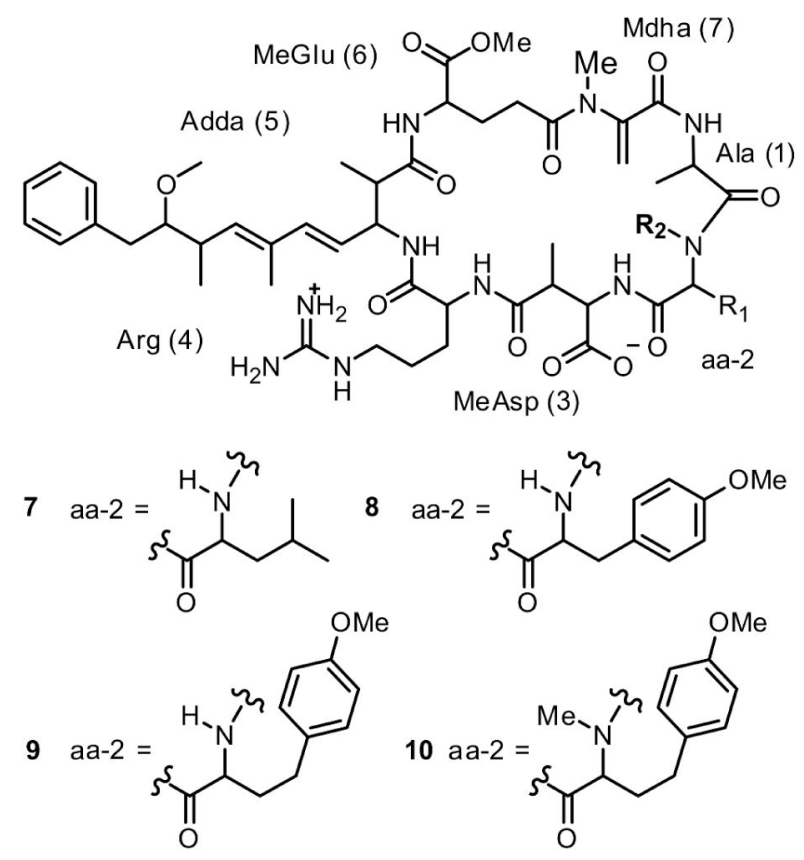

\begin{tabular}{|c|c|c|c|c|}
\hline $\begin{array}{l}\text { fragment } \\
\text { ion }\end{array}$ & & 7 & & 8 \\
\hline$[\mathrm{M}+\mathrm{H}]^{+}$ & 1009.5712 & $\mathrm{C}_{50} \mathrm{H}_{77} \mathrm{~N}_{10} \mathrm{O}_{12}{ }^{+}$ & 1073.5678 & $\mathrm{C}_{54} \mathrm{H}_{77} \mathrm{~N}_{10} \mathrm{O}_{13}{ }^{+}$ \\
\hline a & 875.4977 & $\mathrm{C}_{41} \mathrm{H}_{67} \mathrm{~N}_{10} \mathrm{O}_{11}{ }^{+}$ & 939.4926 & $\mathrm{C}_{45} \mathrm{H}_{67} \mathrm{~N}_{10} \mathrm{O}_{12}{ }^{+}$ \\
\hline$b$ & 553.3085 & $\mathrm{C}_{24} \mathrm{H}_{41} \mathrm{~N}_{8} \mathrm{O}_{7}^{+}$ & 617.3035 & $\mathrm{C}_{28} \mathrm{H}_{41} \mathrm{~N}_{8} \mathrm{O}_{8}^{+}$ \\
\hline$c$ & 470.2712 & $\mathrm{C}_{20} \mathrm{H}_{36} \mathrm{~N}_{7} \mathrm{O}_{6}^{+}$ & 534.2662 & $\mathrm{C}_{24} \mathrm{H}_{36} \mathrm{~N}_{7} \mathrm{O}_{7}^{+}$ \\
\hline$d$ & 613.3700 & $\mathrm{C}_{32} \mathrm{H}_{49} \mathrm{~N}_{6} \mathrm{O}_{6}{ }^{+}$ & 613.3701 & $\mathrm{C}_{32} \mathrm{H}_{49} \mathrm{~N}_{6} \mathrm{O}_{6}^{+}$ \\
\hline$e$ & 696.4069 & $\mathrm{C}_{36} \mathrm{H}_{54} \mathrm{~N}_{7} \mathrm{O}_{7}^{+}$ & 696.4069 & $\mathrm{C}_{36} \mathrm{H}_{54} \mathrm{~N}_{7} \mathrm{O}_{7}^{+}$ \\
\hline$f$ & 767.4443 & $\mathrm{C}_{39} \mathrm{H}_{59} \mathrm{~N}_{8} \mathrm{O}_{8}^{+}$ & 767.4451 & $\mathrm{C}_{39} \mathrm{H}_{59} \mathrm{~N}_{8} \mathrm{O}_{8}{ }^{+}$ \\
\hline$g$ & 880.5282 & $\mathrm{C}_{45} \mathrm{H}_{70} \mathrm{~N}_{9} \mathrm{O}_{9}^{+}$ & 944.5233 & $\mathrm{C}_{49} \mathrm{H}_{70} \mathrm{~N}_{9} \mathrm{O}_{10}{ }^{+}$ \\
\hline$h$ & 896.4866 & $\mathrm{C}_{44} \mathrm{H}_{66} \mathrm{~N}_{9} \mathrm{O}_{11}^{+}$ & 896.4882 & $\mathrm{C}_{44} \mathrm{H}_{66} \mathrm{~N}_{9} \mathrm{O}_{11}^{+}$ \\
\hline$i$ & 742.4127 & $\mathrm{C}_{37} \mathrm{H}_{56} \mathrm{~N}_{7} \mathrm{O}_{9}^{+}$ & N/D & \\
\hline$j$ & N/D & & N/D & \\
\hline$k$ & N/D & & $N / D$ & \\
\hline 1 & 460.2435 & $\mathrm{C}_{24} \mathrm{H}_{34} \mathrm{~N}_{3} \mathrm{O}_{6}{ }^{+}$ & 460.2437 & $\mathrm{C}_{24} \mathrm{H}_{34} \mathrm{~N}_{3} \mathrm{O}_{6}^{+}$ \\
\hline$m$ & 389.2067 & $\mathrm{C}_{21} \mathrm{H}_{29} \mathrm{~N}_{2} \mathrm{O}_{5}^{+}$ & 389.2067 & $\mathrm{C}_{21} \mathrm{H}_{29} \mathrm{~N}_{2} \mathrm{O}_{5}^{+}$ \\
\hline
\end{tabular}

Figure 4.

Structures of methylated MCs obtained by methylation of standard samples of MC-LR (1) and MC-YR (3) and of MC-HtyR (5) and MC-MhtyR (6) from the Green Lake extract, and high-resolution MS/MS fragmentations of the methylated standards which were used to localize the sites of methylation. Fragments that are mass shifted and therefore contain the variable amino acid are labeled in red whereas the non-shifting fragments are labeled in blue. Fragment ions are denoted as shown in Figure 3. 


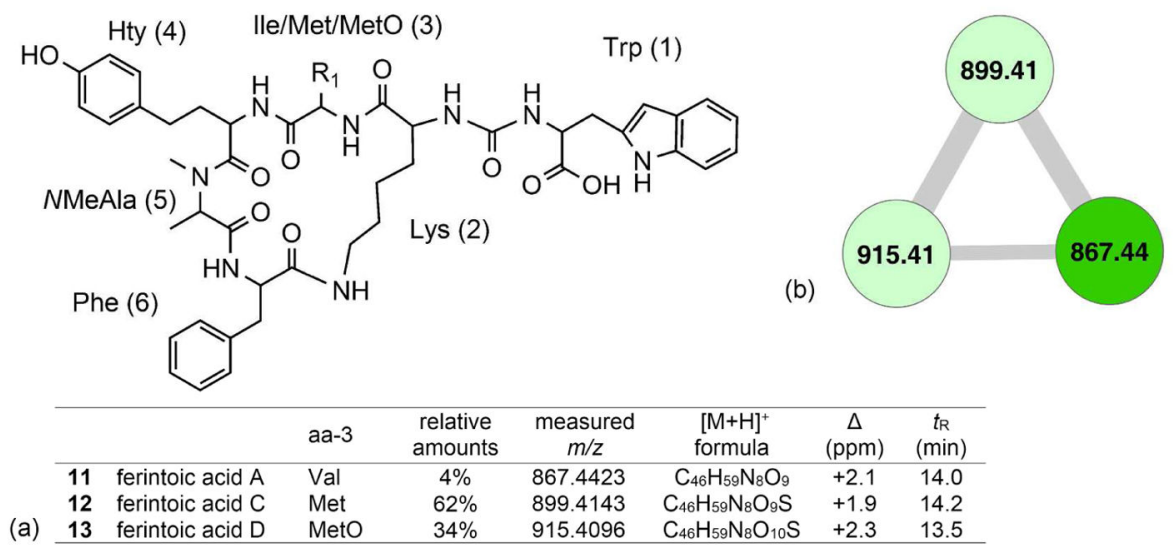

Figure 5.

(a) Structures of ferintoic acids. (b) The ferintoic acid cluster from the Green Lake extract. MetO is methionine sulfoxide. 


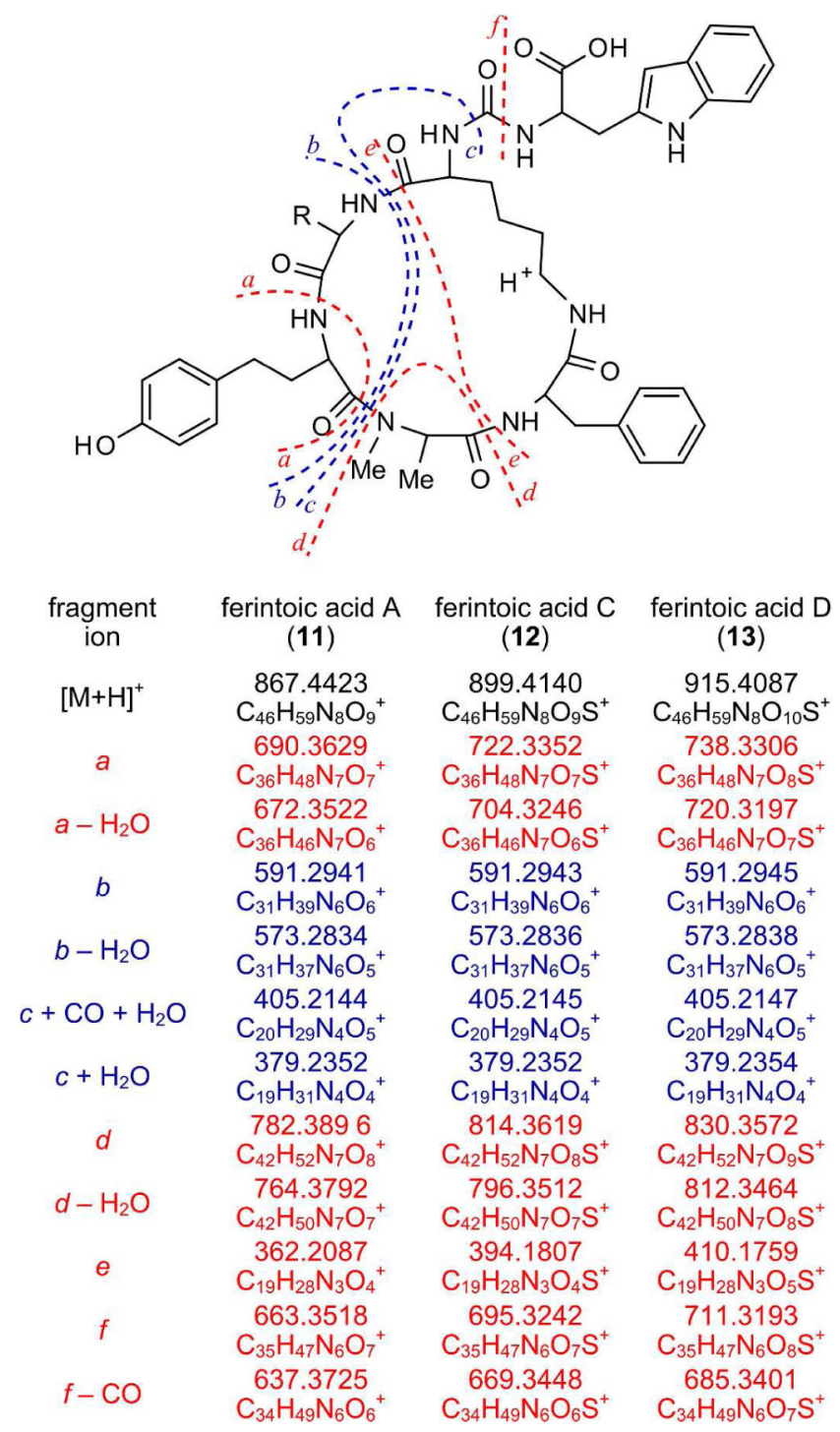

Figure 6.

High-resolution MS/MS fragmentations of ferintoic acids A, C and D. Fragments that are mass shifted and therefore contain the variable amino acid are labeled in red, while the nonshifting fragments are labeled in blue. 


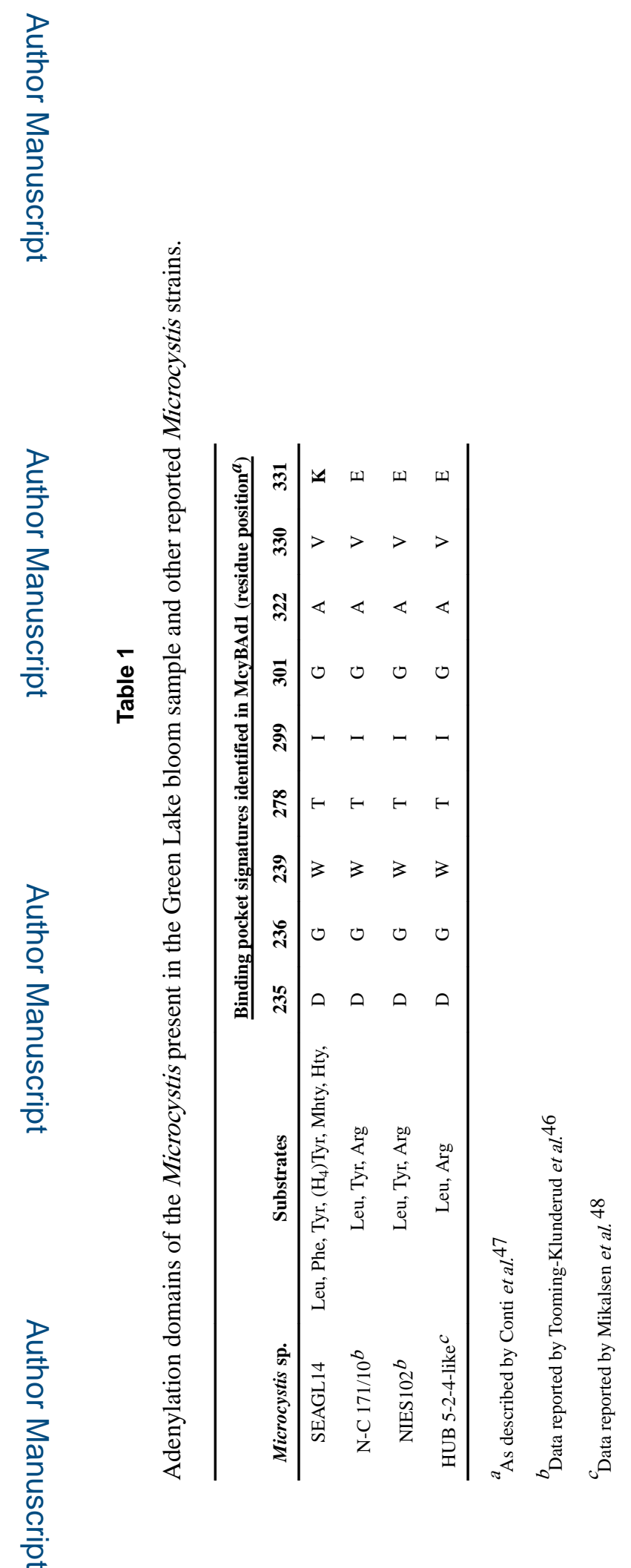

Environ Sci Technol. Author manuscript; available in PMC 2016 December 15. 